\title{
A Comparative Study in Progressive Aspect of Verbal Affixes of Dangha Tharu Dialect with Nepali and English Languages Ram Bahadur Chaudhary ${ }^{1} \&$ Laxmi Bahadur Maharjan ${ }^{2}$
}

${ }^{1} \mathrm{PhD}$ Scholar, Mewar University, Rajasthan, India

${ }^{2}$ Research Supervisor, Professor, Tribhuvan University, Kirtipur, Kathmandu, Nepal

\section{Corresponding Author}

Ram Bahadur Chaudhary

Email: rubysophy@yahoo.com

\begin{abstract}
Dangha is one of the dialects of Tharu language. The alternate names of Dangha language are Dangaura, Dangali, Dangauli, Dangora and Dangura. The population of Dangaura language was 500000 in Nepal in 2003. And the number is increasing. Dangaura language is located in Rapti zone- Dang, Bheri-Bardiya, Banke and Surkhet districts, Seti zone- Kailali district, Mahakali zoneKanchanpur district, Lumbini zone- Rupandehi and Kapilvastu districts. The status of the variety is that it is a recognized indigenous national language in Nepal. That is why it is important to study on the verbal affixes of it. The objective of this study is to find out the similarities and differences of verbal affixes of Dangha with Nepali and English languages. The study has applied qualitative method. Questionnaire and interview were used for primary data collection. The researcher used nonrandom and purposive sampling design to select the samples from the population. He used Eugene A. Nida's six principles for verb analysis. -a, - $\mathrm{i}$ and -ti suffixes are used to mark progressive aspect in Dangha dialect. -a and -i suffixes are used to mark point in time whereas -ti suffix is used to mark period of time. In the same way, suffix -ti is used to mark period of time and point in time in future tense. In Nepali language -tai/dai oreko/eki/ekā suffixes are used to indicate progressive aspect while English use - ing suffix to show progressive aspect. Tharu and English have separate progressive aspect marker for point in time or period of time but Nepali progressive marker can be used for both times simultaneously.
\end{abstract}

\section{KEY WORDS}

Aux, Dialect, Infix, Progressive aspect, Suffix, Verbal affixes

\section{INTRODUCTION}

Tharu language spreads along with the Tharu habitats from east to west of Terrai and inner Terrai in 22 districts of Nepal. It is also used in Bihar, Uttar Pradesh and uttarakhand of India. Rana Tharu language is used in Kailali and Kanchanpur districts (Nepal) and Udham Singh Nagar district, Uttarakhand, Kheri, Uttar Pradesh (India). Kathariya language is used in Kailali district of Nepal and some in India. Dangaura is spread in Dang-Deukhuri, Banke, Bardiya, 
Kailali and Kanchanpur districts of Nepal, Kochila in Bara, Parsa, Rautahat, Sarlahi, saptari, Mahottari and Udaypur districts of Nepal, Pahalman in Inner-terai of Udaypur,Paschuhan (western) in Rupandehi and Nawalparasi districts of Nepal, Rautar in Rupandehi and Nawalparasi districts of Nepal, Purbaha in Rupandehi and Kapilvastu districts of Nepal, Chitwania in Sindhuli, Chitwan and Nawalparsi district of Nepal, Sonha in Surkhet and Bardiya district of Nepal, Rajhatya in Banke and Kailai district of Nepal.

It has many varieties (dialects and sub dialects) but the number is not fixed yet. Eppele et al. (2012) shows there are at least 5 varieties of Tharu language. According to Kharal (1992) there are three dialects Eastern, midwestern and western. Eastern dialect has Morangiya, Saptariya, rajbanshiya subdialects, midwestern has Chitwaniya, Nawalpuriya, and western has Dangaura, Deukhuriya, Kanchanpuriya, Kathariya and Desaure subdialects. Tharu language does not have its own standard form. It belongs to Central Indo Aryan, Indo Iranian, and Indo European language.

Tharu language is used at home, among friends, during religious ceremony, in education (little), at work and in Tharu programmes. Use of this language is spreading day by day. It is also used in magazines, radio programmes, movies, newspapers, books, videos, songs and poetry. This clears the development of Tharu language. While writing this language Devnagri script is used.

Dangha is one of the varieties of Tharu language. The alternate names of Dangaura language are Dangha, Dangali, Dangauli, Dangora and Dangura. The population of Dangaura language was 500000 in Nepal in 2003. And the number is increasing.Dangaura language is located in Rapti zone- Dang, Bheri- Bardiya, Banke and Surkhet districts, Seti zone- Kailali district, Mahakali zone-Kanchanpur district, Lumbinizone- Rupandehi and Kapilvastudistricts. The status of the variety is that it is a recognized indigenous national language in Nepal. It comes under Indo European, Indo Iranian, and Indo Aryan language. Lexical similarity of Dangaha variety is found $85 \%$ with Deukhuri, $83 \%$ with Malhoriya, $72 \%$ $74 \%$ with Sonha, 63\%- 72\% with Rana Tharu, 76\% with Desauriya, 61\%- 67\% with Chitwaniya, $70 \%$ with KathariyaTharu, 58\%- 65\% with Hindi and 46\%- 52\% with KochilaTharu.

Typology of Dangaura language is SOV. Verbal affixation marks person and number, tense-aspect and voice. Word structures are found in CV, CVC and CCV format. It has got 30 consonants and 8 vowel phonemes.

\section{METHODOLOGY}

The study has applied qualitative method. Using the questionnaire and interview, primary data was collected. The researcher used non-random and purposive sampling design to select the samples from the population. In this part, the researcher used journalist to the related language as a filter for the translation or answer the questionnaire. Latter for interview, he used the native speakers of Dangha above 50 years old in age, illiterate and least influenced people by other 
language(s) as a filter. He selected 1 subject for questionnaire and 3 for interview. He used Eugene A. Nida's six principles for verb analysis.

\section{Principle 1}

Forms which have a common semantic distinctiveness and identical phonemic forms in all their occurrences are known as a single morpheme.

\section{Principle 2}

Forms which have a common semantic distinctiveness but which differ in phonemic form (i.e. the phonemes or order of the phonemes) may be known as a morpheme if the distribution of formal differences is phonologically definable.

\section{Principle 3}

Forms which have a common semantic distinctiveness by which differ in phonemic form in such a way that their distribution cannot be phonologically defined constitute a single morpheme provided that the forms are in complementary distribution.

\section{Principle 4}

Differences clearly seen in phonemes or in the order of phonemes are called an overt formal difference. This overt formal difference in a structural series constitutes a morpheme. An overt formal difference and a zero structural difference are the only significant features for distinguishing a minimal unit of phonetic-semantic distinctiveness.

\section{Principle 5}

Homophonous forms can be same or different morphemes on the basis of the following conditions:

a. If the forms give distinctively different meanings, they belong to different morpheme..

b. If the forms give related meaning, they belong to single morpheme.

\section{Principle 6}

Under the following condition, morpheme is isolatable:

a. In isolation- if the unit can stand independently.

b. In multiple combinations- if the element with which it is combined occurs in isolation or in other combinations.

c. In a single combination- some morphemes occur with only one unit and the unit with which it is combined occurs in isolation or in other combinations with no unique constituents. 


\section{RESULTS AND DISCUSSION}

Crystal David (2008) mentions that 'Aspect is a category used in the grammatical description of verbs (along with tense and mood), referring primarily to the way the grammar marks the duration or temporal activity denoted by the verb'.

\section{Dangha}

Following verbs are taken from the primary data of the questions for discussion:

khas $-\mathrm{a}-\mathrm{t} \overline{\mathrm{a}} \rightarrow$ khasațā

fall - Prog (Point) - Aux, 3, Sg, Prest $\quad \rightarrow$ falling is $*$

is falling

pi - ti batyā $\rightarrow$ piți bațyā

drink -Prog (period) Aux, 2, Sg, NHon, Prest $\rightarrow$ drinking have been*

have been drinking

jā $-\mathrm{i} \quad$ țalahyā $\rightarrow \quad$ jāi țalahyā

go - Prog(Point) Aux, 3, Sg, N Hon, Past $\quad \rightarrow$ going was *

was going

ḍgur - ți ralaha $\quad \rightarrow$ ḍagurți ralaha

run - Prog (period) Aux, 3, Pl, N Hon, Past $\quad \rightarrow$ running had been *

had been running

ghum - ți rabi $\quad \rightarrow$ ghumți rabi

roam - Prog (period) Aux, 3, Pl, Hon, Fut $\quad \rightarrow$ roaming will have been $*$

will habe been roaming

(This verbal structure is used for point in time too).
cilla $-\mathrm{i}-$ ța
$\rightarrow$ cillāița 
scream - Prog (Point) - Aux, 3, Pl, N Hon, Prest $\rightarrow$ screaming are *

are screaming

-a and -i suffixes are used to mark point in time whereas -ti suffix is used to mark period of time. In the same way, suffix -ti is used to mark period of time and point in time in future tense. The progressive marker is -a- if root verb ends in consonant sound and -i- if it ends in vowel sound.

As the progressive marker -a and -i differs according to the root verb which ends in vowel or consonant in Dangha, it also differs in Rana Tharu dialect. Progressive marker -at appears if verb stem ends in consonant and - $t$ if it ends in vowel Dhakal (2015). In the Chitoniya Tharu language,suffix -i is used to denote progressive aspect and it is followed by be verbs. Suffix -te can replace -i in future tense Paudyal (2011). Paudel (2052) mentions Dangha speakers use -āi after vowel sound and -a after consonant. But in cillā and jā root, only -i- is used not -āi. He has also mentioned -ti is used for progressive aspect. Chaudhary and Sarbahari (2068), notes perfect continuous form is found in Tharu language as mentioned by the researcher. Dahit (2070) has denoted only perfect continuous marker (period of time) but not continuous marker (point in time). He has mentioned only -ti progressive marker i.e. only perfect continuous marker (period of time). Point in time i.e. continuous marker -i and $-\mathrm{a}$ are also found in Dangha dialect.

\section{Nepali}

According to Bhattarai and Dhungel (2073), root + tai/dai + Aux (thi/cha) or root $+\mathrm{i}+$ rah + eko/eki/ek $\bar{a}+$ Aux (thi/cha) is used to mark progressive marker in Nepali language.

$\mathrm{ja}+$ dai + thiyo

go + prog (Point/Period) + Past, 3, Sg, Mas, N Hon, Aux

padh $+\mathrm{i}+$ rah-eko + thiyo

study + empty morph + Prog (Point/Period)+Past,3, Sg, Mas, N Ho n,Aux.

$\mathrm{ja}+\mathrm{dai}+$ cha

go + Prog $($ Point/Period $)+$ Prest, 3, Sg, Mas, N Hon,Aux

paḍh $+\mathrm{i}+$ rah-eki + hunecha.

study+ empty morph + Prog (Point/Period)+3, Sg, Fem, N Hon, Fut, 3, Sg, Aux. 


\section{English}

In English aux verb is followed by main verb in present participle form to mark progressive aspect (Point).

is + go - ing

Aux, 3, Sg, Prest + root - Prog. (Point)

will + be + go - ing

Aux + be + root - Prog. (Point)

To mark progressive aspect (Period) either has/have/had + been + present participle or will + have + been + present participle form is used.

had + been + looking

Aux + be (Past Participle $)+$ root - Prog (Period).

will + have + been + look - ing

Aux + Aux + be $($ Past Participle $)+$ root - Prog $($ Period $)$

\section{CONCLUSION}

Dangha and English have separate progressive aspect marker for point in time or period of time but Nepali progressive marker can be used for both times simultaneously. In Dangha dialect -a and -i suffixes are used for point in time whereas suffix -ti is used for period of time in all tenses but the suffix -ti is for point in time in future tense only. These suffixes are followed by be verbs to represent past or future. In English root verb with suffix -ing is preceded by be verb to indicate point in time whereas it is preceded by has/have/had+been to indicate period of time. But in Nepali language -tai/dai or eko/eki/ekā suffixes are used to indicate progressive aspect. These suffixes are used for both point in time and period of time.

\section{REFERENCES}

Chaudhary, M. and Sarbahari, K. (2068). Tharu bhasa sikaun (Tharu bhasa sikhi). Sajha Publication, Kathmandu.

Crystal, D. (2008 A.D.). A dictionary of linguitics and phonetics. Blackwell Publishing Ltd.

Dahit,G. (2070 B.S.). Tharu grammar. Unique Nepal, Bardiya.

Eppele et al (2012). Ethnologue: Languages of Nepal. Kathmandu, CDL. TU SIL International. 
Kharal,G.P. (1992). Nepalma boline Tharu bhasikama Nepali bhasako prabhav (Unpublished doctoral dissertation).Banarashi, India.

Nida, E..A. (1949). Morphology: The descriptive analysis of words. The University of Michigon Press, USA.

Dangha. Retrived from https://en.wikipedia.org/wiki/Tharu_People

Paudel, N. K. (2052). A comparative study of grammar of Tharu and Nepali language. (Unpublished MA, Thesis). Tribhuvan University, Nepal

Dhakal, D. (2015). Rana Tharu grammar. Nepal Academy Press.

Paudyal, K. P. (2011).Tense and aspect in the Chitoniya Tharu. Linguistic Society of Nepal. Vol. 26, pp 104-115,ISSN 0259-1006. 